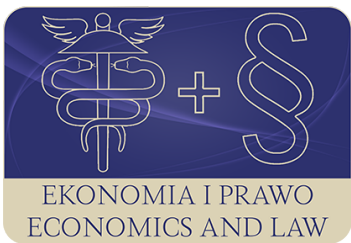

EKONOMIA I PRAWO. ECONOMICS AND LAW

Volume 19, Issue 2, June 2020

p-ISSN 1898-2255, e-ISSN 2392-1625

www.economicsandlaw.pl

EKONOMIA I PRAWO
ECONOMICS AND LAW

ORIGINAL ARTICLE

received 30.03.2019; revised 13.12.2019; accepted 30.06.2020

Citation: Kokot-Stępień, P., \& Krawczyk, P. (2020). The impact of public support on innovative activity of enterprises. Ekonomia i Prawo. Economics and Law, 19(2): 291-304. doi:10.12775/EiP.2020.020.

\title{
The impact of public support on innovative activity of enterprises
}

\section{PATRYCJA KOKOT-STĘPIEŃ}

corresponding author

Czestochowa University of Technology, Faculty of Management, Department of Finance, Banking and Accounting, ul. Dąbrowskiego 69, 42-201 Częstochowa, Poland

$\square$ patrycja.kokot-stepien@wz.pcz.pl

(D) orcid.org/0000-0001-7222-0369

PATRYCJA KRAWCZYK

Czestochowa University of Technology, Faculty of Management, Department of Finance, Banking and Accounting, Poland

$\square$ patrycja.krawczyk@wz.pcz.pl

(D) orcid.org/0000-0002-3814-4603

\begin{abstract}
Motivation: An important factor enabling not only survival, but also the development of enterprises operating in the modern economic reality are innovations whose implementation increases the competitive potential and determines the market position. However, it should be remembered that there are a number of limitations that are reflected in the level of innovation not only of individual entities, but also of the whole country. To increase the scale of investment in research and innovation, the state often becomes responsible for creating an appropriate support system associated with the creation of better conditions for implementing innovative solutions by shaping preferential and privileged operating conditions.

Aim: The aim of the paper is to analyze the innovative activities of enterprises and impact assessment of public financial support for their innovative activity.

Results: Public funding stimulates the innovative activity of enterprises, but does not significantly increase their innovation. It is therefore important to match the co-financing of projects in the field of implementing innovation to the state intervention mechanism and to create support programs promoting projects with high innovation potential.
\end{abstract}

Keywords: public support; public aid; innovations 


\section{Introduction}

One of the factors determining proper functioning of modern enterprises is the ability to create and use innovations constructively. Effective innovation management is a precondition of dynamic growth of economic entities and at the same time affects their competitiveness. Innovative activity makes enterprises adapt themselves better to their environment and respond rapidly to the growing needs and expectations of recipients. However, implementation of innovative undertakings requires ensuring adequate resources, including financial ones obtained from various sources. One of them is enterprises' own contributions coming from generated profits, but they are usually insufficient. Thus, enterprises are compelled to search for alternative funding sources for their innovative activities. However, deciding to resort to such options they must consider the availability of a given source as well as the cost of raising capital and its servicing. Banks often place many obstacles in the way of external funding, such as loans, for small and medium-sized enterprises so as to protect them from excessive risk accompanying innovation projects. Here, government support offers a great assistance. The possibility to use public resources, frequently non-repayable ones, is an important stimulus for enterprises to resolve to implement innovative schemes. Taking into account that the level of innovativeness in case of Polish enterprises is low, it is vital to define the significance of public support in their innovation activity.

The aim of the study is to evaluate innovative activity of enterprises chosen with respect to the type and scope of their business, especially taking into consideration public support for innovations implemented in the years 20082017. In this regard, having analyzed the level of structure and dynamics of both the expenditure on innovation and public support for innovative activity there was examined the relationship between the variables examined beforehand. Critical analysis of the published sources was used in the study, and in the empirical part the authors employed simple statistical methods and the Pearson correlation coefficient enabling examination of the analyzed values. The analysis was carried out on the basis of data concerning the period of 2008-2017 and provided by GUS (2008a-2017a) and UOKiK (2008-2017). Then, it was possible to evaluate changes in the trends of the examined values happening in the course of time.

\section{Literature review}

In the present day, innovation has become a key element of competitive advantage (Prokop \& Stjeskal, 2017, p. 47). Introducing innovations in enterprise depends on innovativeness, that is capacity to participate in innovation process, made up of invention, innovation and diffusion. Innovativeness is ability to make 
innovations real - constant creation of new solutions whose goal is to improve the quality of a given enterprise operation. Innovations contribute to an increase in the value and competitiveness of a company by improving quality, productivity as well as economic and financial performance, increasing customer loyalty, internationalization of activity or upgrading processes and management methods (Matejun, 2018, p. 5). Innovation is the one of key factor for the development enterprise, without due to the industry or size (Krawczyk, 2017, pp. 207-218).

It is frequently emphasized that the level of innovativeness in Poland is low. Some authors point to the barriers preventing effective commercialization of $R \& D$ results, which unfortunately sometimes do not meet the expectations of innovative enterprises (Chybowska et al., 2018, pp. 99-105). However, it has been stated repeatedly that the main barriers constraining innovative activity of the assessed enterprises include financial barriers (Zwolinska-Ligaj \& Adamowicz, 2018, p. 433). One of the preconditions for innovative undertakings to be implemented is the choice of a financing method. Innovation funding aims at acquiring financial resources necessary to bear the costs of implementation of specific innovative schemes. The chance of obtaining them as well as their volume and funding sources are determined by the size of enterprise, its type of ownership, the situation in its environment, but most of all, by the specific innovative undertaking (Kokot-Stępień, 2016, p. 18).

Enterprises may apply for various types of funds, the evaluation of which has been presented inter alia in publication Krawczyk-Sokołowska \& Eukomska-Szarek (2017, pp. 50-58). For the purpose of this paper, the research has been limited to public support for innovative activity comprising two types of expenditures. The first type is budgetary outlays resulting from the use of various instruments such as grants, repayable advances, loans, guarantees or equity, whereas the other type relates to fiscal expenditures being the loss in budgetary revenues which come about due to taxes which have not been paid as a result of exemptions and tax reliefs.

One of the public policy tools used to foster innovation is state aid. According to article 107 (1) of the Treaty on the Functioning of the European Union, state aid is a transfer of state resources which constitutes an economic advantage that the undertaking would not have received in the normal course of business. The advantage is conferred on a selective basis and thereby affects competition and trade in the EU internal market (Kubera, 2016, p. 81). Therefore, state aid supporting innovation in enterprises is permissible only in cases of specific actions undertaken in connection with market failures inhibiting innovation and when the benefits from public support exceed possible disturbances in competitiveness and trade among the EU countries. The obtained support strengthens the position of the enterprise, while reducing the profit on investments of competitors. Thus, when the scope of support is substantial it may make competitors limit their innovative activity and even discourage the very beneficiary of the support from taking on innovation projects (Choroszczak \& 
Mikulec, 2009, pp. 31-32). The control over appropriate allocation of public resources and support intensity is a significant factor in securing effective competition and free trade on the internal market (Podsiadło, 2017, p. 67).

Public aid is a tool of economic policy, which, from the point of view of the protection of competition, is subject to a strict legal regime. On the one hand, these legal regulations control admissibility criteria, which must be met in case of public support, and on the other, they serve as the foundation of its application. The admissibility criteria concerning state aid in the European Union, including the rules pertaining to regional support for enterprises, have been presented in the work by Podsiadło (2016, pp. 771-781).

Each state aid interferes with the market mechanism. Therefore, it is of vital importance to monitor every granted aid. Such monitoring will help to observe what main directions this type of support follows, as well as changes in the allocation of support in different years. The structure and dynamics of public support granted in Poland in the years 2008-2014 have been analyzed by Bartniczak (2017, pp. 40-47). Whereas, Przygodzka (2012, pp. 171-176) has examined the scope and structure of the said support as well as its impact on competition.

One of the types of state aid is regional support. It is granted to entrepreneurs operating in less developed regions in order to spur the economic growth there (Ambroziak, 2016, pp. 245-267; Bartniczak, 2010, pp. 20-23). Lewandowska \& Stopa (2018, pp. 333-351) showed that institutional support systems mitigate negative consequences of the peripheral location of enterprises. Given that innovation is costly and SMEs are too weak in peripheral regions, they underlined that there is great need for reasonable and flexible institutional support systems. In addition, a positive impact of support institutions on enterprise innovation demonstrated Zajkowski \& Domańska (2019, pp. 359-384) in the paper presenting the most important aspect of the entrepreneurial ecosystem in a regional context.

Published sources widely cover innovation issues, but overlook the analysis of use of public resources in the process of financing them. What is generally discussed is what public support is about, conditions of admissibility of applications or just the scale and structure of the obtained public aid. Thus, the research gap with regard to the relationship between public support and the value of expenditure on innovation incurred by Polish enterprises taking into account the scope and type of business has been filled with this study.

\section{Methods}

The tools employed in the research are quantitative methods. Using historical data, the authors attempt to identify the relationship of defined variables. They focus on statistical data published by the Central Statistical Office (GUS, 2008a-2017a) and the Office of Competition and Consumer Protection (UOKiK, 2008-2017). Both high usefulness and credibility are main qualities of the publications issued by these institutions. Information with regard 
to innovative activities undertaken by enterprises and public support for them comes from the annual reports released by GUS (2008a-2017a), while the data on public support was taken from the UOKiK (2008-2017) reports in the years 2008-2017. Allowing for the fact that economic processes frequently have an effect or depend on one another, there will be examined the following research hypotheses:

- Is there a correlation between the value of public support and the amount of expenditure on innovation?;

- Is this correlation determined by the size of business?;

- Is this correlation determined by the type of business (is it an industrial or service enterprise)?

To verify the above-mentioned hypotheses there will be employed a correlation coefficient. The mathematical formula for this coefficient developed by Pearson is:

$$
r_{X Y}=\frac{C(X, Y)}{\sqrt{S_{X}^{2} S_{Y}^{2}}}=\frac{\sum_{i=l}^{n}\left(x_{i}-\bar{x}\right)\left(y_{i}-\bar{y}\right)}{\sqrt{\sum_{i=1}^{n}\left(x_{i}-\bar{x}\right)^{2} \sum_{i=l}^{n}\left(y_{i}-\bar{y}\right)^{2}}}=\frac{C(X, Y)}{S_{X} S_{Y}},
$$

where $C(X, Y)$ means the covariance between features $X$ and $Y, S_{X}{ }^{2}$ and $S_{Y}{ }^{2}$ are the variance of the features $X$ or $Y, S_{X}$ and $S_{Y}$ are the standard deviation of $X$ or $Y$.

The symbol for the Pearson's linear correlation coefficient provides information on the relationship direction of the examined variables, while the absolute value says a lot about its strength (Biatek \& Depta, 2010, p. 54). In this paper, covering the next ten years of the 2008-2017 research period, the variables are the value of innovation expenditure of Polish enterprises and the value of public support for the innovations they implement. In addition, in the last part of the research, one of the variables is the value of public aid focused on increasing the innovation activity of enterprises. In the published sources there are assumed various ranges of the coefficient absolute value to assess the relationship strength. The article uses the scale proposed by Stanisz (1998):

- $|r|=0-$ no correlation;

- $0.0<|r| \leq 0.1$ - faint correlation;

- $0.1<|r| \leq 0.3$ - weak correlation;

- $0.3<|r| \leq 0.5$ - average correlation;

- $0.5<|r| \leq 0.7$ - high correlation;

- $0.7<|r| \leq 0.9$ - very high correlation;

- $0.9<|r|<1.0$ - almost full correlation;

- $|r|=1$ - full correlation.

It should be emphasized that the paper evaluates that part of the correlation between public support and innovation expenditure, which relates to expenditure booked as pro-innovation, although it should be remembered that there is pro-innovation expenditure that is not recorded as such. 


\section{Results}

The extent of innovation activities depends in great measure on the scope of business activity. Implementation of innovative schemes in case of large enterprises, having more access to various types of resources and more inclined to take risk, is much easier than in case of medium-sized or small ones. But, the demand to meet clients' expectations, which are constantly growing or the fear of being left behind by competitors make enterprises introduce changes and implement innovative solutions notwithstanding their business size.

In Poland, the size of expenditure on innovation is not substantial (chart 1 ). In the examined period its value was trending alternately, reaching the lowest level in 2009 (PLN 30912.2 million) and the highest one in 2015 (PLN 43735.1 million). The highest growth rate was reported in 2015 and 2012 (the expenditure increased by 16 and $15 \%$ respectively, as compared with the preceding year). However, taking into account the first and the last year of the analyzed period the expenditure increased by $8 \%$ (from PLN 37948.4 million in 2008 to PLN 41165.6 million in 2017). The biggest influence on the size of expenditure incurred in innovation is exerted by industrial enterprises implementing highly capital-intensive technological innovations. The expenditure incurred by this group of enterprises amounted from 61\% in 2013 to $83 \%$ in the following year. As far as the business size is concerned, the major group in this field is large enterprises whose share of expenditures ranged from 67\% in 2013 to 79\% in 2016). The prevalent source of financing expenditures on innovations is enterprises' own funds, which is often due to limited access to external means of financing, mostly bank loans and the high cost of their acquisition. Another option addressed mainly to medium-sized and small enterprises is funds from the national and the EU budget. Examining the data presented in chart 2 one may notice that in the years 2008-2014 public support for innovations grew regularly, while in 2015 this trend reversed, with a slight initial decline by $3 \%$, but in the next year this type of funding dropped completely, by as much as $71 \%$. Undoubtedly, this was due to the completion of numerous undertakings co-financed by the EU budget under the Multiannual Financial Framework for the years 2007-2013 and the launch of the new one for the next seven years under which many support programmes connected with the growth of innovation in enterprises were not fully set in motion. Fortunately, increasing the use of EU funds in the last year of the examined period, especially in the group of small enterprises, translated into increased expenditure on innovation. Industrial enterprises were the greatest beneficiaries of public resources coming from the government and the EU budget. Enterprises providing services benefited from public resources to a lesser extent because of lower spending on less costly innovations connected with marketing. Although one may notice the highest value of public support in case of large enterprises in some years, their share is inconsiderable, at times even faint after having studied the amounts of expenditures on innovations implemented with the use of resources of this type. 
In the years 2012-2014 the percentage of industrial enterprises which received public financial support on innovation was the biggest and amounted to $29.4 \%$, while between 2011-2013 it was service enterprises that gained public support for innovation on the largest scale $-22.4 \%$ of them. Both the sectors were mostly represented in this field by small and medium-sized enterprises. Majority of economic entities relied on public support obtained from the European Union, including the Seventh Framework Programme for Research and Technological Development of the EU and the Horizon 2020 programme (on average $20 \%$ of industrial enterprises and about $16 \%$ of service sector). As far as resources from the national institutions are concerned the central government resources were more frequently obtained in comparison to the local ones.

Once innovative activities undertaken thanks to public support have been analyzed, the basic part of the research consisting in verification of research hypotheses by means of the Pearson correlation coefficient can be commenced. The correlation results (table 1) for all enterprises, regardless of the scope and type of business confirm substantial interdependence between the amount of the obtained support and the value of expenditure on innovations. As the scale presented in this study shows the value 0.32 indicates an average correlation. Having taken into account the size of business, it turns out that in each case there is a positive dependence between the examined variables, but its value is varied. The correlation was almost full and the examined coefficient reached the highest value at the level of 0.92 in case of enterprises employing up to 49 people. This signifies that public resources coming from the government budget and most of all from the EU budget affect in great measure the scope of innovative activities of small enterprises and remain an important funding source. It should be emphasized that small enterprises, because of insufficient resources, especially financial ones, often decide not to undertake innovative projects, when not given public support. This results in the high interdependence between the examined variables. That is why, a number of structural funds designated to spur the growth of enterprises is connected with innovation process, and the resources from the EU are chiefly directed to small economic entities. It should be borne in mind, however, that enterprises do not receive the whole amount to apportion it as they wish. Moreover, the resources are transferred by way of advances or reimbursements of incurred costs, which means that enterprises must have sufficient own contribution. Thus, the main funding source as far as innovation is concerned is just enterprises' own contribution. In case of enterprises employing between 50 and 249 people the strength of the relationship is much weaker, and the level of 0.47 indicates an average correlation. Without doubt, such a situation is due to the fact that enterprises willing to become more competitive through innovative undertakings do not make their decisions dependent on financial support from public institutions. Besides, very often the expansion of business goes hand in hand not only with the growing access to various types of innovation funding but mainly with becoming more inclined to take risk. However, taking into consideration the whole sector of small 
and medium-sized enterprises (SME) the examined value reached the level of 0.65 indicating a high correlation. Whereas, in case of large enterprises, the analyzed coefficient was slightly more than 0.17 , reaching the line of a weak correlation. Though the amount of public support for this business group was the biggest, when compared to the value of expenditure on innovation, it turned out not to be so noteworthy.

Considering the type of business, it turns out that in case of industrial enterprises there was no correlation. The percentage of public support in the overall sources of financing expenditures incurred by industrial enterprises, which implement capital-intensive technological innovations, when contrasted with own contribution or bank loans was at times just marginal. The situation looked quite different in case of enterprises from the service sector, as they were frequently interested in less expensive innovations concerning organization and marketing. The lower value of implemented innovations made for the fact that the share of public support in expenditures on innovation amounted even to 20\% in 2012. This proves that the possibility to use public resources was a dominant factor in undertaking innovative activities by service companies. The relationship of the examined variables was high, as the correlation coefficient was as much as 0.72 .

Intensifying the research and taking into account the size and type of business at the same time, we can see that the highest, because almost full relationship between the value of public support and the amount of expenditure on innovation takes place in industrial and service enterprises employing up to 49 people, in which the correlation coefficient amounts to 0.95 and 0.92 respectively. As it has already been mentioned, in case of small enterprises the decision whether to undertake innovation projects in great measure depends on the possibility of co-funding of such activities with public resources mainly coming from the EU grants. The correlation was also high in case of entities employing between 50 and 249 people, although in case of industrial enterprises the correlation coefficient amounted to 0.62 and was higher by 0.08 than in case of service companies. This indicates that in the whole sector of SME there is a positive correlation between the examined variables. Because the correlation coefficient reached higher values both in case of small and medium-sized industrial enterprises, the relationship between the value of public support and the amount of expenditure on innovation for the whole sector is very high, as it equals 0.78 . The lower value of the correlation coefficient in case of medium-sized service enterprises translated to the weaker relationship between the examined variables, which for the service enterprises of the SME sector was equal to 0.65. The average correlation (0.55) also occurred in service enterprises employing more than 250 people, in which, because of the lower expenditure than in large industrial enterprises, the significance of this type of funding of innovative activities was considerable. The situation looked entirely different in industrial economic entities employing more than 250 people. The research shows that there is a negative average relationship between public support and their inno- 
vation undertakings (the correlation coefficient is -0.45). Out of all enterprises it is large industrial enterprises that incur the highest expenditures on innovations, as they finance them, like all economic entities, mostly with their own resources. Long periods of examining co-funding applications and frequent allocations of public resources to smaller enterprises do not have a positive impact on the innovative activity of this business group. Moreover, the financial support instruments which are offered do not always suit their preferences or absorption ability. One must not forget about substantial limits in granting public support to large economic entities, which often have a strong market position, as granting of such support in any form always leads to the distortion of competition on the free market.

The main form of public support for business activity is the one which covers horizontal, regional and sectoral support. Within the framework of horizontal support, the financial resources, mostly in the form of grants, are designated to research, growth and innovation (chart 3). The value of support in this regard grew regularly till 2012 (more than a sevenfold increase from the level of PLN 173.6 million to PLN 1298.8 million), then in the following year the trend reversed and remained unchanged till 2014 (initially the drop was 29, and then $43 \%)$. However, in the consecutive year the level of horizontal support for the said projects started to grow again and this trend stayed the same till the end of the analyzed period, that is in 2017 reaching its peak - PLN 5017.5 million. Comparing the value of this support with the amount of expenditure on innovation, one may notice a positive average correlation at the level of 0.46. Innovative activities were also boosted within the framework of sectoral support, whose value was connected with granting public support co-funded from the EU resources mainly by the President of the Polish Agency for Enterprise Development. Having taking into account the support obtained within the framework of programmes supporting innovative activity of enterprises and the amount of expenditure on innovation, it turns out that the correlation amounted to 0.61 , which proves a high relationship between public support and innovative activities undertaken by economic entities.

\section{Conclusion}

Implementation of innovations requires substantial capital expenditures, the return of which can be expected only after a few years. Moreover, they involve a lot of risk, which makes for limited access to external funding sources. Financing innovative activities mainly by means of own resources is reflected in the amount of expenditure on innovation. State aid may be a perfect solution in case of insufficiency of own resources, since they provide public funding and thus, boost innovative activity of enterprises. Although public support serves to prompt enterprises to undertake specific schemes, it is necessary to provide a level playing field for all market participants and to this end this type of aid must be under control. 
The possibility of obtaining public support has a positive effect on innovation activity, especially in case of small enterprises, which more than others need this type of aid to implement innovation projects. Their own resources are quite limited, and they face difficulties in gaining access to external funding sources. The existence of the relationship between public support and the amount of expenditures on innovations has been proved by the analysis in which the Pearson correlation coefficient was used. In case of economic entities employing up to 49 people this relationship turned out to be very high, both for industrial and service enterprises. That is why, one may assume that the instruments of support granted to them were adequate and fit their capacities and needs. In case of medium-sized enterprises the correlation was average, however, the correlation between examined variables was higher for industrial enterprises than for service sector. Whereas, in case of large industrial entities the correlation was negative, which means that the instruments of support and enterprises' preferences and capabilities must have been mismatched. Taking into account the public aid itself one could observe a positive relationship between its value and the amount of expenditure on innovations. It should be noted that the correlation in case of regional aid was much higher than in case of horizontal aid designated for strictly defined projects.

\section{References}

Ambroziak, A.A. (2016). Income tax exemption as a regional state aid in special economic zones and its impact upon development of Polish districts. Oeconomia Copernicana, 7(2). doi:10.12775/OeC.2016.015.

Bartniczak, B. (2010). Granting regional state aid in Poland. In P. Jedlicka (Ed.), Hradecke ekonomicke dny 2010: ekonomicky rozvoj a management regionu. Hradec Kralove: University of Hradec Kralove.

Bartniczak, B. (2017). The analysis of state aid granted in Poland in years 20082015. In Jedlicka P., Maresova P., \& Soukal, I. (Eds.), Hradec Economic Days 2017. Kralove: University of Hradec Kralove.

Białek, J., \& Depta, A. (2010). Statystyka dla studentów z programem STAT_STUD 1.0. Warszawa: C.H. Beck.

Choroszczak, J., \& Mikulec, M. (2009). Pomoc publiczna a rozwój firmy: szanse i zagrożenia. Warszawa: Poltext.

Chybowska, D., Chybowski, L., \& Souchkov, V. (2018). R\&D in Poland: is the country close to a knowledge-driven economy? Management Systems in Production Engineering, 26(2). doi:10.1515/mspe-2018-0016.

GUS. (2008a-2017a). Dziatalność innowacyjna przedsiębiorstw. Retrieved 12.12.2019 form http://stat.gov.pl.

GUS. (2008b-2017b). Nauka i technika. Retrieved 12.12.2019 form http://stat. gov.pl. 
Kokot-Stępień, P. (2016). Finansowanie działalności innowacyjnej w Polsce. Zeszyty NaukowePolitechniki Częstochowskiej: Zarządzanie, 24(1). doi:10.17512/ znpcz.2016.4.1.02.

Krawczyk, P. (2017). Kapitał ludzki i innowacyjność jako determinanty dalszego rozwoju sektora MSP w Polsce. Zeszyty Naukowe Politechniki Śląskiej: Organizacja i Zarządzanie, 113. doi:10.29119/1641-3466.2017.113.16.

Krawczyk-Sokołowska, I., \& Łukomska-Szarek, J. (2017). Public and Private Financing of Innovative Activity of Enterprises in Poland. Zeszyty Naukowe Politechniki Częstochowskiej: Zarządzanie, 27(2). doi:10.17512/ znpcz.2017.3.2.05.

Kubera, P. (2016). Additionality of state aid for research, development and innovation. Zeszyty Naukowe Politechniki Poznańskiej: Organizacja i Zarządzanie, 68.

Lewandowska, A., \& Stopa, M. (2018). SMEs innovativeness and institutional support system: the local experiences in qualitative perspective. Polish case study. Oeconomia Copernicana, 9(2). doi:10.24136/oc.2018.017.

Matejun, M. (2018). The process of opportunities exploration and exploitation in the development of SMES' innovativeness. Management and Production Engineering Review, 9(3). doi:10.24425/119529.

Podsiadło, P. (2016). Regional state aid and its impact on the competitiveness of the EU member states. In E. Kovarova, L. Melecky, \& M. Stanickova (Eds.), Proceedings of the 3rd international conference on European integration 2016. Ostrava: Technical University of Ostrava.

Podsiadto, P. (2017). The efficiency of granting state aid in the EU member states: myth or reality? Problemy Zarządzania, 15(67). doi:10.7172/1644-9584.67.3.

Prokop, V., \& Stjeskal, J. (2017). Different approaches to managing innovation activities: an analysis of strong, moderate, and modest innovators. Engineering Economics, 28(1). doi:10.5755/j01.ee.28.1.16111.

Przygodzka, R. (2012). The state aid for enterprises in Poland. In P. Jedlicka (Ed.), Hradec Economic Days 2012. Kralove: University of Hradec Kralove.

Stanisz, A. (1998). Przystępny kurs statystyki w oparciu o program Statistica PL na przyktadach z medycyny. Kraków: Statsoft Polska.

UOKiK. (2008-2017). Raport o pomocy publicznej $w$ Polsce udzielonej przedsiębiorcom. Retrieved 12.12.2019 form https://uokik.gov.pl.

Zajkowski, R., \& Domańska, A. (2019). Differences in perception of regional pro-entrepreneurial policy: does obtaining support change a prospect? Oeconomia Copernicana, 10(2). doi:10.24136/oc.2019.018.

Zwolinska-Ligaj, M.A., \& Adamowicz, M. (2018). Innovative activity of enterprises in the peripheral region. In A. Auzina (Ed.), Economic science for rural development: proceedings of the international scientific conference. Jelgava: LUA Faculty of Economics. doi:10.22616/ESRD.2018.050. 


\section{Acknowledgements}

Author contributions: authors have given an approval to the final version of the article. Authors contributed to this work equally.

Funding: this research was funded by the Czestochowa University of Technology, Faculty of Management statutory sources.

Note: the results of this study were presented at 10th International Conference on Applied Economics Contemporary Issues in Economy (June 27-28, 2019, Torun, Poland). 


\section{Appendix}

Table 1.

Correlation table of public support and the expenditure on innovation

\begin{tabular}{llccc}
\hline \multirow{2}{*}{ Correlation } & \multicolumn{2}{c}{ Type of business } & \multirow{2}{*}{ Total } \\
\cline { 3 - 4 } & small & industrial & services & 0.92 \\
\multirow{3}{*}{ scope of business } & 0.95 & 0.92 & 0.47 \\
& medium & 0.62 & 0.54 & 0.65 \\
& SME & 0.78 & 0.65 & 0.17 \\
total & large & -0.45 & 0.55 & 0.32 \\
\hline
\end{tabular}

Source: Own preparation based on GUS (2008a-2017a).

Chart 1.

Expenditures on innovation in Poland in years 2008-2017 (in mln PLN)

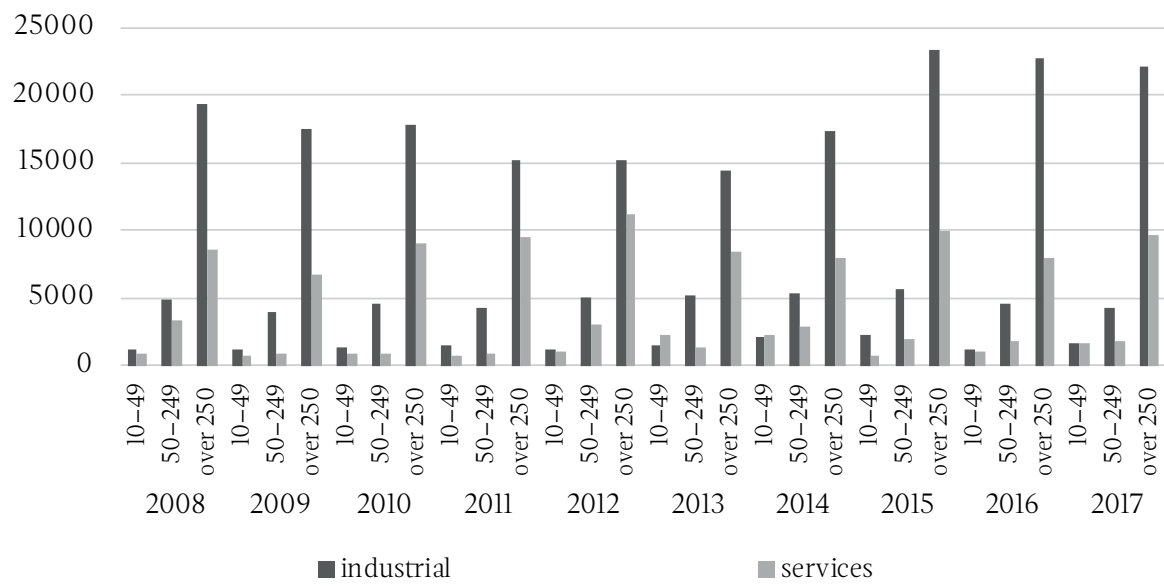

Source: Own preparation based on GUS (2008a-2017a; 2008b-2017b). 
Chart 2.

Public support for innovative activity in years 2008-2017 (in mln PLN)



Source: Own preparation based on GUS (2008a-2017a; 2008b-2017b).

Chart 3.

Public aid for innovative activity in years 2008-2017 (in mln PLN)

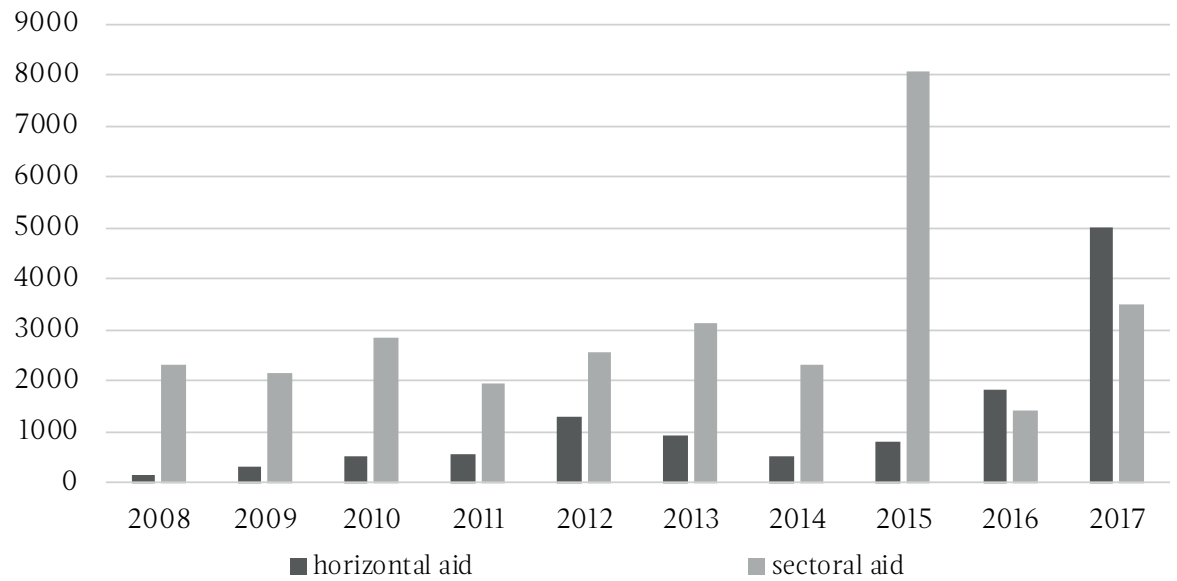

Source: Own preparation based on UOKiK (2008-2017). 